\title{
The Effect of Corporate Social Responsibility Reporting on Financial Performance in Libya and Jordan
}

\author{
Abdulhamid Ali Abukil ${ }^{1}$, Imam Ghozali ${ }^{2}$, Puji Harto ${ }^{3}$
}

\begin{abstract}
:
This paper investigates the effect of corporate social responsibility reporting on financial performance use triple bottom line of 130 stock market companies in developing countries Libya and Jordan. Twenty reporting criteria were developed for evry line of reporting areas: economic, social, and environmental categories.
\end{abstract}

We construct of corporate social responsibility reporting index based on global reporting initiative guidelines. Corporate social responsibility reporting toward financial performance examined by data collected from website annual reports. The sample included companies criteria used to select availability data for a period of 5 years (2008-2012). SPSS analysis used to examine hypothesis consistent with stakeholder theory and signalling theory proxied by tools of measurement use return on assets, return on equity, and return on liabilities.

This result controlled by variables, size of firms and type of industry by linear regression analysis. Based on the analysis and result corporate social responsibility reporting in Libya and Jordan still not optimistic, that affected by triple bottom line and higher corporate social responsibility reporting is associated with financial performance.

Our findings imply that global reporting initiative guidelines organize corporate social responsibility reporting.

Keywords: corporate social responsibility reporting, triple bottom-line, financial performance, global reporting initiative, Libyan stock market, Amman stock exchange.

\footnotetext{
${ }^{l}$ PhD candidate, in Accounting at faculty of economics and business in Diponegoro University,a_abukil@yahoo.com

${ }^{2}$ Professor in accounting in Diponegoro University, ghozali_imam@yahoo.com

${ }^{3}$ Associate professor in accounting in Dipnegoro University, pujharto@gmail.com
} 


\section{Introduction}

The area of corporate social responsibility has become a notable topic both in the business field and academic research. In developed countries and in developing countries too. Corporate social responsibility reporting is interesting topic to be discussed. Corporate social responsibility has grown rapidly because most of active companies engaged in serious efforts to integrate corporate social responsibility into all aspects of their business programmes, this also resulting in effect to others such as stakeholders for example shareholders, employees, financiers, supplier, analysts, regulators, activists, community organizations, customers, trade union and government by directly contributing. According to this effect should corporate social responsibility reporting pay attention to all of those categories. Companies should explain to stakeholders in corporate social responsibility reports not only what investments they are making, but why they are making those specific investment decisions and how it affects both to company and society. Corporate social responsibility reporting of many firms in developing countries is lack because there are two active questions why and how answers behind their corporate social responsibility initiatives (Palmer, 2012). A corporate should be responsible for all stakeholders, including its shareholders, employees, customers, suppliers and the community.

A company must not only describe corporate social responsibility programs, but persuade stakeholders why the benefits of such investments override the price increases for every stakeholder. Meanwhile, corporate social responsibility is an action by a firm, which the firm chooses to take, that substantially affects an identifiable social stakeholder's welfare. This will involve the integration of comprehensive set on policies, practices, and programs that related to business operations, supply, decision-making processes, environmental, human rights, etc. Corporate social responsibility reporting is important strategy made by firms. Finance managers needed to optimize the best financing method in other maximize their firms' performance by utilizing the discussed in literature review among them (Anlesinya et al., 2014; Palmer, 2012; Campbell, 2012).

It was also being studied in Arabic countries such as in Libya (Alghodban et al., 2015). Also in Jordan (Almajali et al., 2012). This study is important for some reasons first, because corporate social responsibility much important and related to financial performance also corporate social responsibility reporting has secondary attention and companies getting many claims that have been carrying out social responsibility reporting like develop financial performance and survive as well. Awareness about the importance of practicing corporate social responsibility reporting is a global trend in line with the widespread concern of prioritizing stakeholders. Advances in information technology and market transparency,in developing countries, like Libyan and Jordan companies should pay attention for corporate social responsibility reporting seriously and openly as corporate social responsibility reporting has many benefits for developing countries. Second, 
emerging economies are a big part from the world those countries need more to improve and add literature about the developing countries also corporate social responsibility reporting in website anuual report especially when using global reporting initiative as guide line for social activities in emerging stock market that suffer from administrative confusion. Third, the limitation of previous research studies in developing countries like (Bayoud, 2012; Saleh, 2001). both studies pointed out the Libyan gap. Fourth, lately corporate social responsibility reporting much intersting discussed issue in the world because the companies getting many claims for financial performance and survive that have been carrying out social responsibility reporting. Moreover there are a few studies about corporate social responsibility done in Arabic area like Libya and Jordan and is not related to website reporting it was done quite lone time ago.

\section{Literature Review and Hypothesis Development}

Corporate social responsibility reporting is an important concept that aims to improve social responsibility while putting social value is part of firms value. Researchers in this field have highlighted corporate social responsibility as importance from different overview. Stakeholder theory has become focal point of a great many debates. Its current tendency is to impose a point of reference by imitating corporate social responsibility policies (Pesqueux et al., 2005). stakeholer theory suggests there is a positive relationship between corporate social responsibility and financial performance (Jones, 1995). That we need order to increase the value of the firm.

Cheng et al. (2006) find that firms with strong shareholder rights tend to have a lower cost of equity capital than competing firms, which supports the idea that reducing agency problems between stakeholders and management for improves firms performance in terms of financial performance. This suggests that in case of large companies, good managerial practice does indeed improve the bottom line (Darus et al., 2013). The relationship between corporate social performance and financial performance has been interesting topic from many researchers such as (Waddock and Graves, 1997; Griffin and Mahon, 1997; McWilliams and Siegel, 2000). The empirical studies result for corporate social responsibility toward financial performance that some of this result have been non-agreement and some studies determined negative correlation, some determined positive correlation, while others determined no correlation. Previous studies done by Anlesinya et al. (2014) concluded that corporate social responsibility reporting did not affecting financial performance. Martinez and Bosque (2013) showed that corporate social responsibility has positive affect on financial performance, this also supported by (Mishra and Suar, 2010). On the other hand, McWilliams and Siegel (2000) results from these studies can roughly be grouped into those with results showing negative relationship between corporate social responsibility reporting and financial performance. Most of those studies justify that result according to cost and benefit that related to program of corporate social responsibility and the size of firms that 
become problem statement in this research for the relationship between corporate social responsibility reporting and firms' financial performance (Giannakopoulou et al., 2016). Also, one of research problems is reporting for what information can be reported to give corporate social responsibility reporting as necessary requirement in firms, and what information should be reported and should be supported by stakeholders and satisfy for them.

On the other hand, many studies has found that relationship between the level of corporate social responsibility and performance of the organization in terms of financial performance, measures and indicators of a companies according to financial ration that use in this study are return on assets,return on equity, and return on liabilities. The sample for this study is restricted to all websites companies because companies that have websites annual report are mostly large listed companies. (Darus et al., 2013) and get advantage as easy to use, low cost (Branco and Rodrigues, 2008). Although the linkage between corporate social responsibility and firm financial performance is as effect is found not clear and deep in developing countries in literature reviews, Therefore, this study hypothesizes that corporate social responsibility reporting and financial performance have causal relationship.

Moreover, the relationship between corporate social responsibility and financial performance will show through a profound consideration of variable control such as the size of firm and the type of industry (Yazid and Suryanto, 2016). The relationship between corporate social responsibility reporting and financial performance supported by stakeholder theory that explained about the relationship of company with stakeholders as positive relationship. If the influence is positive, with the goal of profit maximization, then the firms will allocate more resources to socially responsible programs and achieve better financial performance. Previous study shows in Fortanier (2011) opinion stated that corporate social responsibility is affected by their visibility and higher performance. In Wood (2010) opinion located a positive correlation between social responsibility and accounting performance after controlling for the age of assets. In Waddock and Graves (1997) found significant positive relationships between an index of corporate social responsibility and performance measures. Hence, the hypothesis is stated as follows:

\section{Hla: Corporate social responsibility reporting has positive influence on financial performance (ROA).}

Corporate social responsibility reporting as activities if induce negative effects, then firms may adopt a conservative attitude and be more cautious fo corporate social responsibility reporting issues. Therefore, clarifying the relationship between corporate social responsibility reporting and financial performance is critically meaningful for the promotion of corporate social responsibility reporting implementation and reporting in any firm. In John Elkington (2001) strove to measure sustainability during the mid-1990s called the triple bottom line went beyond the traditional measures of profits, return on investment, and shareholder 
value to include environmental and social dimensions. Triple bottom line reporting can be an important tool to support corporate social responsibility reporting goals and compering costs and benefits to maximize value of firms. The relationship between corporate social responsibility and financial performance still has a gap for reporting by using triple bottom line by different measurements also the relationship can be interpreted negatively relationship. The argument for the negative relationship follows the thinking of people like Friedman that their view has companies that are socially responsible have a competitive disadvantage, because they expend directly on the bottom line and reduce profits, while these costs can be avoided or covered by individual or government. As such, next hypothesis is:

\section{H1b: Corporate social responsibility reporting has negative influence on financial performance (Financial leverage).}

Organizations have the flexibility to decide what information to report use global reporting initiative guidelines covers all aspects of information reporting. Study done by (Gamerschlag et al., 2011). stated that German companies using economy, social and environmental dimension of corporate social responsibility reporting affecting higher firm's performance. The corporate social responsibility reporting affecting financial performance especially in terms of financial performance. However, there study examines the relationship between some measure of corporate social performance and financial performance that explore the relationship between social responsibility and accounting-based performance measures have also produced mixed results. In Wood (2010) opinion located a positive correlation between social responsibility and accounting performance after controlling for the age of assets. Based on the description and argument above, so the hypothesis is:

H1c: Corporate social responsibility reporting has positive influence on financial performance (Liquidity).

\section{Research Methodology}

In this research a quantitative approach was adopted for empirical investigation. In this study stock market is one of the sources of capital for enterprises operating in a given economy. However, the significance of this part of the financial system for the whole economy in some stock markets do not exist or their mechanisms do not function properly, where as in others their sizes in relation to the whole economies are particularly large (Marszk, 2013). This study get Libyan and Jordan firms that listed in stock market and use the same firms for all the 5 years study. The final sample include totally (130) firms as sample size from different sectors that are considered as corporate social responsibility reporting have the same effect or not. In this study, companies listed in Libyan stock market and Jordan stock market from 2008 to 2012 are selected as sample size as secondary data can be financial and non financial data. The source of data for corporate social responsibility from websites available annual report for 5 years that has been published because Libya and Jordan 
does not produce a standalone report or sustainability report but are published as a section for corporate social responsibility in annual reports.

The corporate financial performance measurement is based on the data taken from the annual report as return on assets, return on equity, and return on liabilities (Waddock and Graves, 1997). The main objective of this study is to examine the effect of the corporate social responsibility reporting by three dimensions using triple bottom line on financial performance, to achieve that, determined the reporting companies in two countries. The method of data analysis used is linear regression analysis for descriptive statistic and testing of classical assumptions that will be conducted such as a test of normality, multi colinearity, heteroscedasticity, and autocorrelation, in order to meet the nature of the regression estimation. This study employs regression analysis as the main statistical method, when corporate social responsibilityis an independent variable and financial performance is a dependent variable (McWilliams et al., 2000) as shown:

$$
\begin{aligned}
& \mathrm{ROA}=\alpha+\beta 1 \text { CSRreporting }+\beta 2 \text { Size }+\beta 3 \text { TYPE }+\mathrm{e} \\
& \mathrm{DER}=\alpha+\beta 1 \text { CSRreporting }+\beta 2 \mathrm{Size}+\beta 3 \mathrm{TYPE}+\mathrm{e} \\
& \mathrm{LIQ}=\alpha+\beta 1 \text { CSRreporting }+\beta 2 \mathrm{Size}+\beta 3 \mathrm{TYPE}+\mathrm{e}
\end{aligned}
$$

ROA denotes return on asset which was derived from net income after tax over total assets. It reflects dependent variable varying across section and time. Previous studies such as (Hribar et al., 2014) used this proxy as measurement of performance. Meanwhile, DER is measured by the ratio return on equity. Liquidity is proxied by current assets over current liabilities and size of the firm is proxied by the logarithm of total assets, type of industry as dummy variable. In past studies of the link between corporate social responsibility and financial performance, control variables included size (Ullman, 1985; Waddock and Graves, 1997). and type of industry (Lin et al., 2015). To render the research results more complete.

\section{Results}

Linear regression analysis was used to assess the influence of corporate social responsibility towards financial performance. Preliminary analyses were conducted to ensure the assumptions of normality, linearity, multicollinearity, and homoscedasticity. The regression results are presented as follows:

Table 1. The regression analysis of corporate social responsibility on financial performance

\begin{tabular}{|l|l|l|l|}
\hline Variables & Model (1) ROA & Model (2) DER & Model (3) LIQ \\
\hline CSR_reporting & -0.059 & 3.625 & -2.511 \\
\hline Ln_size & -0.005 & 7.537 & -1.085 \\
\hline Type & 0.120 & -0.092 & 0.225 \\
\hline P value & $0.004^{* *}$ & $0.005^{*}$ & $0.003^{* *}$ \\
\hline Beta value & -0.099 & 0.159 & -0.274 \\
\hline
\end{tabular}




\begin{tabular}{|l|l|l|l|}
\hline Adjusted $\mathrm{R}^{2}$ & 0.892 & 0.700 & 0.363 \\
\hline F- Test & 276.746 & 79.634 & 16.358 \\
\hline DW-Test & 1.801 & 1.838 & 2.004 \\
\hline $\mathrm{P}<0.10 ; * \mathrm{p}<0.05 ; * * \mathrm{p}<0.01 ; * * * \mathrm{p}<0.001$ \\
\hline
\end{tabular}

In model one $\mathrm{p}$ value $=0.004$ is significantly but Beta value $=(0.099)$ by negative value. Adjusted R2 means the correlation between independent variable and dependent variable for this model Adjusted R2 $=0.892$ is high association between independent variable and independent variable. value for $\mathrm{F}$ test is concluded the overall regression model is a good fit for the data, and independent variable statistically significantly predict the independent variable $F=276.746$. From DWtest is $=1.801$ between du (1.5) and $4-\mathrm{du}(2.5)$ the data in this model is free from autocorrelation. In model two $p$ value $=0.005$ is significantly but Beta value $=0.159$ by positive value affect.

Adjusted R2 means the correlation between independent variable and dependent variable for this model Adjusted R2 $=0.700$ is means the percentages independent variables affecting dependent variables are $70 \%$ after adjustment with standard error, is means high association between independent variable and independent variable. $F$ test is concluded the overall regression model is a good fit for the data. Independent variable statistically significantly predict the independent variable $F=79.634$. From DW- test is $=1.838$ between du (1.5) and 4- du (2.5) the data in this model is free from autocorrelation.

In model three $\mathrm{p}$ value $=(0.003)$ is significantly but Beta value $=(0.274)$ by negative value. Adjusted R2 means the correlation between independent variable and dependent variable, for this model Adjusted R2 $=0.363$ is high association between independent variable and independent variable. $\mathrm{F}$ test is $=16.358$ concluded the overall regression model is a good fit for the data, and independent variable statistically significantly predict the independent variable. From DW- test is $=2.004$ between $\mathrm{du}$ (1.5) and 4- du (2.5) so the data in this model is free from autocorrelation.

\section{Discussion}

In model one research results show that corporate social responsibility reporting activity has negative influence for listed companies in Libya and Jordan, This situation of the result can be explained by several resones. In Libya and Jordan, like many developing countries corporate social responsibility started lately, and not clear that corporate social responsibility affect financial performance because most of firms not included non financial data in annual report clearly. Based on the result there is negative influence of corporate social responsibility reporting on financial performance H1a will be reject. 
This is not supported by stakeholder theory that was expanded by Donaldson and Preston (1995) who stressed the moral and ethical dimensions of corporate social responsibility, as well as the business case for engaging in such activity. The growing corporate social responsibility awareness is also reflected in the increasing number of corporate social responsibility reporting, as well as in the provision of corporate social responsibility related information (Gray et al., 2001). In model two consistant with result the significant of corporate social responsibility reporting relevant to financial performance so it can be say that there is positive influence of corporate social responsibility reporting on financial performance and $\mathrm{H} 1 \mathrm{~b}$ rejected. This findings consistent with signaling theory that stated information published as an announcement will provide a signal for investors in investment decision.

According to some studies like Berrone et al. (2007) ensure the quality of financial data to improve reporting to internal stakeholders, in order to increase confidence of investors and other stakeholder groups. In mldel three there is negative influence of corporate social responsibility reporting on financial performance (Liquidity) and H1c rejected. This findings not supported by stakeholder theory and previous study done by Fortanier et al., (2011) that stated corporate social responsibility reporting are affected by their visibility and performance. The higher corporate social responsibility reporting, so it can be said that there was negative relationship between corporate social responsibility reporting and financial performance.

This finding not consistent with previous study done by (Gamerschlag et al., 2011). But this result supported by previous study done by (Edward and Elizabeth, 2008). Corporate social responsibility reporting for small companies need more cash, so the higher corporate social responsibility reporting that will make company affecting the lower liquidity.

\section{Conclusion}

Corporate social responsibility reporting is research field for the academic over the world. And the purpose of this study is to test the relationship between corporate social responsibility reporting and financial performance in two developing countries (Libya and Jordan). To get a better understanding of corporate social responsibility reporting. Based on stakeholder theory we used some specific accounting indicators and conduct an empirical study for 130 Libyan and Jordanian listed companies to test impacts of corporate social responsibility reporting on financial performance. In this study evaluates the impact of corporate social responsibility reporting on the financial performance of firms, both in short-term and long-term.

We measure corporate social responsibility reporting in terms of financial performance for this purpose used linear regression analysis on a sample of data over a time period of 2008 till 2012, In order to validate the impact of corporate social responsibility reporting to financial performance and employ two control variables one is size of firms and the other type of industry. Reviewing the research result of 
investigating the relationship between corporate social responsibility and financial performance in Libya and Jordan traded companies it can be concluded that no significant relationship can be observed for the sample during the time period 20082012 of firms listed in Libya and Jordan.

The results indicate that, for total triple bottom line reporting (combining economic, social, and environmental categories), the extent of reporting is no significantly higher effect to Libyan and Jordanian firms with mixed sector. Overall, the results of empirical analysis are consistent with Libya and Jordan of corporate social responsibility reporting, that is: although corporate social responsibility in both countries had a certain degree of development, the overall situation is still not optimistic. Currently, Libya and Jordan corporate social responsibility reporting remains focus on the responsibilities need to develop.

\section{References:}

Alghodban, A., Albahlol, M., Nathasa, M. 2015. Corporate Social Responsibility Disclosure In Libyan Companies. International Journal of Business, Economics and Law, 8(1), ISSN 2289-1552.

Almajali, Y., Alamro, A., Al-Soub, Z. 2012. Factors affecting the financial performance of Jordanian insurance companies listed at Amman Stock Exchange. Journal of Management Research, 4(2), 266-289.

Anlesinya, A., Joseph, A., Fatimatu, B., Appoh, W., Zakari, B. 2014. The Effect of Corporate Social Responsibility on Financial Performance of MTN Ghana Limited. International Journal of Thesis Projects and Dissertations (IJTPD), 2(1), 1-8.

Bayoud, N. 2012. An Empirical Study of the Relationship Between Corporate Social Responsibility Disclosure and Organizational Performance: Evidence From Libya. International Journal of Management and Marketing Research, 5(3), 69-82.

Berrone, P., Surroca, J., Tribó, A. 2007. Corporate ethical identity as a determinant of firm performance: A test of the mediating role of stakeholder satisfaction. Journal of Business Ethics, 76(1), 35-53.

Branco, C., Rodrigues, L. 2008. Factors influencing social responsibility disclosure by Portuguese companies. Journal of Business Ethics, 83(4), 685-701.

Campbell, B. 2012. Corporate Social Responsibility and development in Africa: Redefining the roles and responsibilities of public and private actors in the mining sector. Resources Policy, 37(2), 138-143.

Darus, F., Hamzah, K., Yusoff, H. 2013. CSR web reporting: The influence of ownership structure and mimetic isomorphism. Procedia Economics and Finance, 7, 236-242.

Donalson, E., Preston, L. 1995. The stakeholder theory of the corporation; Concepts, Evidence and Implications. Academy of Management Review, 20(1), 65-91.

Edward, N., Elizabeth, W. 2008. Corporate social responsibility and financial performance: the virtuous circler revisited. Review of Quantitve Financial and Accounting, 32(2).

Elkington, J. 2001, The triple bottom line for 21 st century business. The Earthscan reader in business and sustainable development, 20-43.

Fortanier, F., Kolk, A., Pinkse, J. 2011. Harmonization in CSR reporting. Management International Review, 51(5), 665-696. 
Gamerschlag, R., Klaus, M., Frank, V. 2011. Determinants of voluntary CSR disclosure: Empirical evidence from Germany. Review of Management Scinces, 5, 233-262, DOI 10.1007/s11846-010-0052-3.

Giannakopoulou, N.E., Stamatopoulos, V.T. and Thalassinos, I.E. 2016. Corporate governance in shipping: An overview. Maritime Policy and Management, Vol. 43(1), 19-38.

Gray, R. 2001. Thirty years of social accounting, reporting and auditing: What (if anything) have welearnt? Business Ethics: A European Review, 10(1), 9-15.

Griffin, J., Mahon, F. 1997. The corporate social performance and corporate financial performance debate: Twenty-five years of incomparable research. Business \& society, 36(1), 5-31.

Hribar, P., Kravet, T., Wilson, R. 2014. A new measure of accounting quality. Review of Accounting Studies, 19(1), 506-538.

Jones, M. 1995. Instrumental stakeholder theory: A synthesis of ethics and economics. Academy of Management Review, 20, 404-437.

Lin, S., Chang, Y., Dang T. 2015. An integrated model to explain how corporate social responsibility affects corporate financial performance. Sustainability, 7(7), 82928311.

Marszk, A. 2013. Macroeconomic functions of the Russian stock market. Proceedings in ARSA-Advanced Research in Scientific Areas, (1).

Martínez, P., Del Bosque, R. 2013. Introduction to the academic perspectives of CSR measurement. International letters of social and humanistic sciences, 2, 51-55.

McWilliams, S. 2000. Corporate social responsibility and financial performance: Correlation or Misspecification? Strategic management Journal, 21(5), 603-609.

Mishra, S., Damodar, D. 2010. Does Corporate Social Responsibility Influence Firm Performance of Indian Companies? Journal of Business Ethics, 95, 571-601, DOI 10.1007/s10551-010-0441-1.

Palmer, J. 2012. Corporate Social Responsibility and Financial Performance: Does it Pay to Be Good? CMC Senior Theses. Paper 529. Claremont McKenna College.

Pesqueux, Y., Damak, S. 2005. Stakeholder theory in perspective. Corporate Governance: The international journal of business in society, 5(2), 5-21.

Saleh, M. 2001. Accounting Information Disclosure and Accountability: Cases from Libya, $\mathrm{PhD}$ thesis. Sheffield Hallam University.

Ullmann, A. 1985. Data in search of a theory: A critical examination of the relationships among social performance, social disclosure, and economic performance of US firms. Academy of management review, 10(3), 540-557.

Waddock, A., Graves, B. 1997. The corporate social performance-financial performance link. Strategic management journal, 303-319.

Wood, D.J. 2010. Measuring corporate social performance: a review. International Journal of Management Reviews, 12, 50-84.

Yazid, H., Suryanto, T. 2016. An Investigation of Factors Influencing Audit Quality According to Islamic Audit: A Study for the Jakarta Islamic Index. International Journal of Economics and Business Administration, 4(1), 20-38. 